\title{
Effects of Zinc Lactate Supplementation on Growth Performance, Intestinal Morphology, Serum Parameters, and Hepatic Metallothionein of Chinese Yellow-Feathered Broilers
}

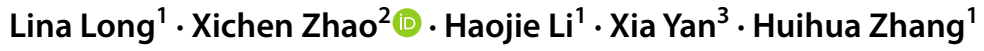

Received: 24 March 2021 / Accepted: 8 June 2021 / Published online: 17 June 2021

(c) The Author(s) 2021

\begin{abstract}
In poultry, organic zinc compounds have higher bioavailability than inorganic zinc sources. However, as an organic zinc source, the application of zinc lactate (ZL) on Chinese yellow-feathered broilers has been rarely reported. Hence, the present study aimed to investigate the effects of ZL supplementation on growth performance, small intestinal morphology, serum biochemical parameters, immune organ index, as well as hepatic metallothionein of Chinese yellow-feathered broilers. A total of 2100 broilers (19 days old) were randomly assigned to 5 treatment groups, including the control (fed basal diet), ZL40 (basal diet plus $40 \mathrm{mg} / \mathrm{kg}$ ZL), ZL60 (basal diet plus $60 \mathrm{mg} / \mathrm{kg} \mathrm{ZL),} \mathrm{ZL80} \mathrm{(basal} \mathrm{diet} \mathrm{plus} 80 \mathrm{mg} / \mathrm{kg} \mathrm{ZL),} \mathrm{and} \mathrm{ZS80}$ (basal diet plus $80 \mathrm{mg} / \mathrm{kg}$ ZS. Each treatment group had 6 replicates with 70 chickens per replicate. Compared to the control group, the ZL40 and the ZS80 groups had a lower feed to gain ratio $(P<0.05)$, ZL40 group had higher duodenum and ileum villus heights $(P<0.05)$, and ZS80 and ZL80 groups had a lower ratio of villus height to crypt depth in the jejunum $(P<0.01)$. In addition, the ZL60 group had a higher concentration of total protein $(P<0.05)$ and activity of glutathione peroxidase $(\mathrm{GSH}-\mathrm{Px})(P<0.01)$ compared with the ZS80 and the control groups. Interestingly, the ZL40, ZL60, and ZL80 groups all had higher levels of hepatic metallothionein than the other groups $(P<0.01)$. In conclusion, zinc lactate had a higher bioavailability and could be used as an alternative to zinc sulfate.
\end{abstract}

Keywords Zinc lactate $\cdot$ Broiler $\cdot$ Growth performance $\cdot$ Serum parameter $\cdot$ Metallothionein

\section{Introduction}

Zinc ( $\mathrm{Zn})$, as one of the trace minerals, serves as a co-factor of hundreds of endogenous enzymes and thousands of transcription factors involved in the various biochemical

Lina Long and Xichen Zhao contributed equally to this work.

Xichen Zhao

fenziyy@126.com

$\triangle$ Huihua Zhang

hhzhang2@163.com

1 School of Life Science and Engineering, Foshan University, Foshan 528231, China

2 College of Animal Science, South China Agricultural University, Tianhe District, 483Wushan Road, Guangzhou 510642, China

3 Institute of Animal Science, State Key Laboratory of Livestock and Poultry Breeding, Guangdong Academy of Agricultural Sciences, Guangzhou 510640, China metabolic events in the body and thus indispensable to animals [1-4]. Zn deficiency can cause pathological changes, decrease growth, reduce immunity, as well as promote the production of free radicals, which lead to oxidative damage to animals [5, 6]. The NRC (1994) [7] recommends $40 \mathrm{mg} / \mathrm{kg}$ dietary zinc for commercial broiler chickens to prevent zinc deficiency [8]. Studies showed that higher zinc intake $(60 \sim 180 \mathrm{mg} / \mathrm{kg})$ promotes the digestive function of animals including increased activities of digestive enzymes and improved intestinal morphology as well as function $[9,10]$. Therefore, the zinc requirement of broilers recommended by NRC (1994) might be outdated. Inorganic zinc (zinc sulfate, zinc oxides, etc.) is mainly used in poultry production to maximize performance [11-13]. Unfortunately, supplementing inorganic zinc may cause environmental pollution due to low bioavailability $[14,15]$. In recent years, organic forms of zinc (zinc methionine, zinc glycine, etc.) have been used in poultry production to replace inorganic zinc due to its higher bioavailability $[1,9,16,17]$. 
Previous studies demonstrated that dietary supplementation of organic zinc increased weight gain and improved the feed efficiency of broilers $[2,8]$.

Zinc lactate (ZL) is organic zinc and has been used in animal diets. A previous study revealed that dietary supplementation of zinc lactate $(100 \mathrm{mg} / \mathrm{kg})$ significantly improved the small intestinal morphology (increased the villus length and decreased crypt depth), nutrient utilization, and thereby improved the growth performance of pigs [18]. In growing rabbits, zinc lactate supplementation $(80 \mathrm{mg} / \mathrm{kg}$ ) improved the small intestinal morphology and growth performance. Zinc content in the liver was also increased [19]. Studies on IPEC-J2 epithelial cells treated with zinc lactate showed promoted cell proliferation and upregulated metallothionein 1 [20]. However, studies of ZL in the poultry industry have been limited, especially on the slow-growing broilers such as Chinese yellow-feathered broilers. The optimum dosage of zinc lactate in broilers' diet remains uncertain. Therefore, the present study was carried out to determine the effects of dietary zinc lactate on the growth performance of Chinese yellow feather broilers compared with that of feed-grade zinc sulfate. The optimal dosage of dietary zinc lactate on yellow-feathered broilers would also be evaluated as a reference zinc source in a slow-growing broilers diet.

\section{Materials and Methods}

\section{Experimental Design, Animals, and Housing}

A total of 2100 Chinese yellow-feathered broilers (male, 19 days old) were randomly divided into five groups including the control (basal diet), ZL40 (basal diet plus $40 \mathrm{mg} /$ $\mathrm{kg} \mathrm{ZL),} \mathrm{ZL60} \mathrm{(basal} \mathrm{diet} \mathrm{plus} 60 \mathrm{mg} / \mathrm{kg}$ ZL), ZL80 (basal diet plus $80 \mathrm{mg} / \mathrm{kg} \mathrm{ZL}$ ), and ZS80 (basal diet plus $80 \mathrm{mg} /$ $\mathrm{kg}$ ZS). Each group had six replicates with 70 chickens per replicate. The experimental diets were formulated according to the NRC (1994) and met the recommended requirements of growing broilers. All broilers had free access to feed and water and were housed in the floor pens $(3.5 \mathrm{~m} \times 2.0 \mathrm{~m} \times 1.0 \mathrm{~m})$ under the same environmental conditions. A 23:1 light-dark regime was used throughout the trial. The newly hatched birds were housed in a room that had a temperature of $34 \sim 36{ }^{\circ} \mathrm{C}$, and the temperature was reduced by $3{ }^{\circ} \mathrm{C}$ each week until 4 weeks later ( 28 days old).

\section{Records, Calculations, and Sampling}

The body weight (BW) and feed intake were recorded (TCS$150,0.05 / 150 \mathrm{~kg}$, Rongcheng, China) on days 19, 38, and 62 in the morning. The average daily feed intake (ADFI), average daily gain $(\mathrm{ADG})$, and feed to gain ratio $(\mathrm{F} / \mathrm{G})$ were calculated according to the values of $\mathrm{BW}$ and feed intake during the trial. Approximately $100 \mathrm{~g}$ of feed samples were collected, blended, and then stored in a $-20^{\circ} \mathrm{C}$ freezer (BCD-321 W, Robert Bosch, Germany) for future analysis of $\mathrm{Zn}$ content.

Six broilers were randomly selected from each treatment group on days 38 and 62 . Before slaughtering, a $\sim \mathrm{ml}$ of blood sample was collected from each chicken after at least 12-h fasting. Blood samples were kept still at room temperature for $2 \mathrm{~h}$ and then centrifuged (CT14RD II, Shanghai, China) at $3000 \times \mathrm{r}$ for $10 \mathrm{~min}$ at room temperature. The serum was collected and stored at $-80^{\circ} \mathrm{C}$ freezer (Panasonic MDF-U74V, Japan) until further analysis. After slaughtering, the spleen, thymus, and bursa of Fabricius were separated and weighted (DT200, $0.2 / 200 \mathrm{~g}$, Brother, America). The organ indices were calculated [21]. Segments of duodenum, jejunum yolk phloem, and ileocecal orifice from broilers on day 62 were collected, rinsed with cold phosphate-buffered saline (PBS), and immobilized in 4\% formaldehyde for $24 \mathrm{~h}$. Liver samples were collected and stored at $-80{ }^{\circ} \mathrm{C}$ for further analysis.

\section{Chemical Analysis}

The content of $\mathrm{Zn}$ in feed samples determined by an atomic absorption spectrometer (AA-7000, SHIMADZU, Japan) [22] (Tables 1 and 2). The serum concentration of albumin (A028-2-1), total protein (A045-4-2), and the enzyme activities of alkaline phosphatase (A059-2-2), glutathione peroxidase (GSH-Px) (A005-1-2), and superoxide dismutase (SOD) (A001-1-2) were determined by using commercial assay kits (Nanjing Jiancheng Bioengineering Institute, China) according to the manufacturer's instructions.

\section{Small Intestinal Morphology}

Intestinal samples were embedded in paraffin wax firstly, and three consecutive Sects. $(5 \mu \mathrm{m})$ were stained with hematoxylin-eosin for analysis. Villus height and crypt depth were measured by using a microscope (LEICA RM2235, Olympus, Japan) at $40 \times$ magnification. A total of $20 \sim 30$ villus and their associated crypt per section were randomly selected, and villus length and crypt depth were analyzed by MShot Image Analysis System (MD50-T, Guangzhou, China).

\section{Real-Time PCR}

Standard procedures of total RNA extraction and reverse transcription were conducted according to the instructions of RNA extraction kits and cDNA Synthesis SuperMix kit (TransGen Biotech, Beijing, China). Specific primer sequence for metallothionein was referred to the previous relevant study [23]; $\beta$-actin was selected as a housekeeping gene and then synthesized by Sangon Biotech (Shanghai, China). The results of qPCR were obtained by a particular 
Table 1 Ingredients and composition of the experimental diet (as-fed basis)

\begin{tabular}{|c|c|c|c|c|c|}
\hline \multirow[t]{2}{*}{ Ingredients (\%) } & \multicolumn{2}{|l|}{ Stage } & \multirow[t]{2}{*}{ Nutrient levels } & \multicolumn{2}{|l|}{ Stage } \\
\hline & $19 \sim 37$ & $38 \sim 61$ & & $19 \sim 37$ & $38 \sim 61$ \\
\hline Corn & 63.46 & 65.46 & $\mathrm{ME}(\mathrm{MJ} / \mathrm{kg})$ & 12.54 & 12.96 \\
\hline Soybean meal & 28.00 & 24.00 & $\mathrm{CP}(\%)$ & 18.63 & 17.60 \\
\hline Salt & 0.30 & 0.30 & Lys (\%) & 0.99 & 0.92 \\
\hline Limestone & 1.41 & 1.41 & Met (\%) & 0.46 & 0.42 \\
\hline Monocalcium phosphate & 1.33 & 1.33 & $\mathrm{Ca}(\%)$ & 0.88 & 0.84 \\
\hline Soybean oil & 2.50 & 3.50 & $\mathrm{AP}(\%)^{2}$ & 0.40 & 0.38 \\
\hline Corn gluten meal & 2.00 & 3.00 & Zinc (ppm) & 31 & 28 \\
\hline Premix $^{1}$ & 1.00 & 1.00 & & & \\
\hline Total & 100.0 & 100.0 & & & \\
\hline
\end{tabular}

${ }^{1}$ Supplied per kilogram of diet: VA, 6000 IU; VD3, 2000 IU; VE, 30 mg; VK3, 2 mg; VB1, 3 mg; VB2, $5 \mathrm{mg}$; pantothenic acid, $800 \mathrm{mg}$; choline chloride, $1500 \mathrm{mg}$; nicotinic acid, $30 \mathrm{mg}$; pyridoxine, $3 \mathrm{mg}$; folic acid, $500 \mathrm{mg}$; biotin, $0.2 \mathrm{mg}$; VB12, $1 \mathrm{mg}$; Fe, $80 \mathrm{mg}$; Cu, 8 mg; Mn, 80 mg; I, 0.35 mg; Se, 0.3 mg; Co, $0.2 \mathrm{mg}$

${ }^{2} A P$, available phosphorus detection system (Applied Biosystems, Foster City, USA) and the following protocol used was $3 \mathrm{~min}$ at $95{ }^{\circ} \mathrm{C}$ and then for 45 cycles of amplification $\left(3 \mathrm{~s}\right.$ at $95^{\circ} \mathrm{C}$ and $30 \mathrm{~s}$ at $\left.60^{\circ} \mathrm{C}\right)$. Data were calculated using the $2^{-(\Delta \Delta \mathrm{Ct})}$ method [24].

\section{Statistical Analysis}

Statistical analyses were performed by using the one-way ANOVA procedure of SAS software (SAS 8.1, Inst, Inc., Cary, NC), and multiple comparison was conducted using the Duncan method. If the data did not comply with the normal distribution or homogeneity, the Kruskal-Wallis test was used. Statistical significance was declared at $P<0.05$ and trends at $0.05<P<0.10$.

\section{Results}

\section{Growth Performance}

As shown in Table 3, compared with the control, ZL40 and ZS80 groups had a lower feed to gain ratio during 19 37 days $(P<0.05)$. However, the treatment did

Table 2 Concentrations of zinc in the diets (calculated, $\mathrm{mg} / \mathrm{kg}$ )

\begin{tabular}{llllll}
\hline Items & ZL40 $^{1}$ & ZL60 $^{1}$ & ZL80 $^{1}$ & ZS80 $^{2}$ & Control \\
\hline $19 \sim 37 \mathrm{~d}$ & 71 & 91 & 111 & 111 & 31 \\
$38 \sim 61 \mathrm{~d}$ & 68 & 88 & 108 & 108 & 28 \\
\hline
\end{tabular}

${ }^{1}$ Supplemented with zinc lactate on the basal diet, and the additive dosage was $40 \mathrm{mg} / \mathrm{kg}, 60 \mathrm{mg} / \mathrm{kg}, 80 \mathrm{mg} / \mathrm{kg}$, respectively; $Z L$, zinc lactate

${ }^{2}$ Supplemented with zinc sulfate on the basal diet, and the additive dosage was $80 \mathrm{mg} / \mathrm{kg} ; Z S$, zinc sulfate not affect the BW, ADG, ADFI, and feed to gain ratio (38 61 days) of the broilers. This suggested that supplementing ZL improved the feed efficiency of slow-growing broilers during the early period.

\section{Slaughter Performance and Immune Organ Index}

As shown in Tables 4 and 5, neither inclusion of the ZL nor the ZS in the broiler's diet had an impact on the slaughter performance such as dressing percentage and immune organ index like thymus $(P>0.05)$.

\section{Intestinal Morphology}

No significant difference in the ratio of villus height to crypt depth in duodenum and ileum was observed. Compared with the control, villus height of duodenum was increased in treatment ZL40, and villus height of ileum was also enhanced in ZL40, ZL60, and ZL80 $(P<0.05)$. Villus height in the ZL80 group was higher than ZL40 and crypt depth in ZL80 was lower than ZL40. Hence, the villus height to crypt depth ratio in ZL80 was higher than ZL40. Moreover, the villus height to crypt depth ratio in ZL80 was also higher than that in control $(P<0.05)$. It was suggested that increasing the dietary dosage of ZL promoted the development of jejunum of broiler chickens. In addition, compared with the control, crypt depth in ZS80 decreased $(P>0.05)$ and villus height to crypt depth ratio increased $(P<0.05)$. These showed that both supplementations with $80 \mathrm{mg} / \mathrm{kg} \mathrm{ZL}$ or $80 \mathrm{mg} / \mathrm{kg}$ ZS promoted the development of jejunum of broilers. 
Table 3 Effects of zinc lactate supplementation on growth performance of broilers

\begin{tabular}{lllllllll}
\hline Items & & ZL40 $^{1}$ & ZL60 $^{1}$ & ZL80 $^{1}$ & ZS80 $^{2}$ & Control & SEM & $P$-value $^{3}$ \\
\hline BW (g) & $19 \mathrm{~d}$ & 235.66 & 235.96 & 235.01 & 233.54 & 236.52 & 0.92 & 0.91 \\
& $38 \mathrm{~d}$ & 839.54 & 822.74 & 806.92 & 802.09 & 804.86 & 7.05 & 0.44 \\
& $62 \mathrm{~d}$ & 1793.79 & 1824.59 & 1752.58 & 1736.17 & 1799.02 & 21.37 & 0.73 \\
ADG (g) & $19 \sim 37 \mathrm{~d}$ & 31.78 & 30.88 & 30.1 & 29.92 & 29.91 & 0.36 & 0.44 \\
& $38 \sim 61 \mathrm{~d}$ & 39.76 & 41.74 & 39.4 & 38.92 & 41.42 & 0.67 & 0.67 \\
& $19 \sim 61 \mathrm{~d}$ & 36.23 & 36.94 & 35.29 & 34.94 & 36.34 & 0.49 & 0.74 \\
ADFI (g) & $19 \sim 37 \mathrm{~d}$ & 62.34 & 62.63 & 60.53 & 60.06 & 62.11 & 0.68 & 0.66 \\
& $38 \sim 61 \mathrm{~d}$ & 104.87 & 105.35 & 101.28 & 99.77 & 104.96 & 1.01 & 0.27 \\
& $19 \sim 61 \mathrm{~d}$ & 86.08 & 86.47 & 83.28 & 82.23 & 86.02 & 1.06 & 0.60 \\
F/G & $19 \sim 37 \mathrm{~d}$ & $1.96^{\mathrm{b}}$ & $2.03^{\mathrm{ab}}$ & $2.01^{\mathrm{ab}}$ & $2.00^{\mathrm{b}}$ & $2.08^{\mathrm{a}}$ & 0.01 & 0.047 \\
& $38 \sim 61 \mathrm{~d}$ & 2.63 & 2.63 & 2.54 & 2.59 & 2.53 & 0.02 & 0.62 \\
& $19 \sim 61 \mathrm{~d}$ & 2.37 & 2.33 & 2.36 & 2.35 & 2.36 & 0.01 & 0.83 \\
\hline
\end{tabular}

${ }^{1}$ Supplemented with zinc lactate on the basal diet, and the additive dosage was $40 \mathrm{mg} / \mathrm{kg}, 60 \mathrm{mg} / \mathrm{kg}$, $80 \mathrm{mg} / \mathrm{kg}$, respectively; $Z L$, zinc lactate

${ }^{2}$ Supplemented with zinc sulfate on the basal diet, and the additive dosage was $80 \mathrm{mg} / \mathrm{kg} ; \mathrm{ZS}$, zinc sulfate

${ }^{3}$ Data were obtained by one-way ANOVA, and difference significance was obtained by Duncan's multiple comparisons (repetition $n=6$ )

\section{Serum Biochemical Parameters}

As shown in Table 6, compared with the control, the content of serum total protein at day 38 increased $(P<0.05)$ in ZL60 and serum albumin tended to be higher. Furthermore, compared with the control and ZS80, the activity of GSHPx increased $(P<0.01)$ in ZL40, ZL60, and ZL80 at day 62, with ZL60 being the highest. Compared with the control, the activity of alkaline phosphatase in ZL80 and ZS80 tended to be higher $(P=0.053)$ than that in ZL40. These suggested
Table 4 Effects of zinc lactate supplementation on slaughter performance and immune organ index of broilers

\begin{tabular}{lllllllll}
\hline Items & & ZL40 $^{1}$ & ZL60 $^{1}$ & ZL80 $^{1}$ & ZS80 & Control & SEM & $P$-value \\
\hline Dressing percentage (\%) & $38 \mathrm{~d}$ & 91.58 & 92.72 & 91.48 & 90.51 & 92.24 & 0.33 & 0.28 \\
& $62 \mathrm{~d}$ & 90.15 & 91.03 & 91.58 & 90.13 & 91.23 & 0.29 & 1.00 \\
Breast meat percentages (\%) & $38 \mathrm{~d}$ & 13.04 & 14.11 & 14.14 & 15.70 & 14.35 & 0.38 & 0.37 \\
& $62 \mathrm{~d}$ & 15.93 & 15.97 & 16.31 & 15.39 & 15.61 & 0.14 & 0.39 \\
Thigh meat rate (\%) & $38 \mathrm{~d}$ & 20.90 & 23.46 & 21.18 & 20.89 & 20.61 & 0.44 & 0.31 \\
& $62 \mathrm{~d}$ & 22.06 & 23.03 & 21.65 & 22.14 & 22.37 & 0.32 & 0.19 \\
Abdominal fat percentage (\%) & $38 \mathrm{~d}$ & 3.00 & 2.67 & 2.98 & 2.88 & 3.18 & 0.26 & 0.99 \\
& $62 \mathrm{~d}$ & 2.65 & 3.60 & 3.03 & 2.68 & 3.81 & 0.18 & 0.92 \\
Percentage of eviscerated yield (\%) & $38 \mathrm{~d}$ & 61.07 & 62.62 & 59.79 & 62.40 & 61.18 & 0.50 & 0.57 \\
& $62 \mathrm{~d}$ & 67.24 & 66.95 & 67.67 & 65.87 & 67.22 & 0.37 & 0.88 \\
Semi-eviscerated weight (\%) & $38 \mathrm{~d}$ & 77.92 & 79.24 & 76.18 & 77.38 & 77.61 & 0.38 & 0.32 \\
\multirow{3}{*}{ Thymus (mg/g) } & $62 \mathrm{~d}$ & 81.92 & 81.56 & 82.68 & 81.35 & 82.36 & 0.31 & 0.93 \\
& $38 \mathrm{~d}$ & 2.71 & 3.40 & 4.35 & 2.07 & 3.31 & 0.37 & 0.62 \\
Spleen (mg/g) & $62 \mathrm{~d}$ & 2.03 & 2.62 & 2.30 & 2.18 & 2.07 & 0.13 & 0.83 \\
& $38 \mathrm{~d}$ & 1.54 & 1.07 & 1.72 & 0.96 & 1.27 & 0.10 & 0.18 \\
Bursa of Fabricius (mg/g) & $62 \mathrm{~d}$ & 1.39 & 1.33 & 1.28 & 1.32 & 1.28 & 0.08 & 0.69 \\
& $38 \mathrm{~d}$ & 2.96 & 2.93 & 4.59 & 2.91 & 3.49 & 0.24 & 0.33 \\
& $62 \mathrm{~d}$ & 0.80 & 1.39 & 1.30 & 0.95 & 0.90 & 0.09 & 0.67 \\
\hline
\end{tabular}

${ }^{1}$ Supplemented with zinc lactate on the basal diet, and the additive dosage was $40 \mathrm{mg} / \mathrm{kg}, 60 \mathrm{mg} / \mathrm{kg}$, $80 \mathrm{mg} / \mathrm{kg}$, respectively; $Z L$, zinc lactate

${ }^{2}$ Supplemented with zinc sulfate on the basal diet, and the additive dosage was $80 \mathrm{mg} / \mathrm{kg} ; \mathrm{ZS}$, zinc sulfate ${ }^{3}$ Data were obtained by one-way ANOVA, and difference significance was obtained by Duncan's multiple comparisons (repetition $n=6$ ) 
Table 5 Effects of zinc lactate supplementation on intestinal morphology of broilers

\begin{tabular}{llllllrl}
\hline Items & ZL40 $^{1}$ & ZL60 $^{1}$ & ZL80 $^{1}$ & ZS80 $^{2}$ & Control & SEM & $P$-value $^{3}$ \\
\hline $\begin{array}{l}\text { Duodenum } \\
\text { Villus height }(\mu \mathrm{m})\end{array}$ & $1720.48^{\mathrm{A}}$ & $1485.40^{\mathrm{BC}}$ & $1513.78^{\mathrm{B}}$ & $1429.49^{\mathrm{BC}}$ & $1327.87^{\mathrm{C}}$ & 30.48 & 0.0005 \\
Crypt depth $(\mu \mathrm{m})$ & 327.36 & 302.77 & 314.36 & 308.27 & 302.89 & 7.18 & 0.83 \\
V/C & 4.77 & 4.69 & 5.15 & 4.99 & 4.30 & 0.14 & 0.37 \\
Jejunum & & & & & & & \\
Villus height $(\mu \mathrm{m})$ & $1236.59^{\mathrm{BC}}$ & $1147.24^{\mathrm{C}}$ & $1368.61^{\mathrm{A}}$ & $1220.80^{\mathrm{BC}}$ & $1302.43^{\mathrm{AB}}$ & 20.09 & 0.0089 \\
Crypt depth $(\mu \mathrm{m})$ & $365.34^{\mathrm{A}}$ & $247.86^{\mathrm{C}}$ & $264.34^{\mathrm{BC}}$ & $202.53^{\mathrm{D}}$ & $304.84^{\mathrm{AB}}$ & 11.76 & 0.0002 \\
V/C & $3.59^{\mathrm{D}}$ & $4.75^{\mathrm{BC}}$ & $5.29^{\mathrm{AB}}$ & $6.25^{\mathrm{A}}$ & $4.15^{\mathrm{CD}}$ & 0.22 & 0.0001 \\
Ileum & & & & & & & \\
Villus height $(\mu \mathrm{m})$ & $1327.68^{\mathrm{a}}$ & $1286.46^{\mathrm{a}}$ & $1314.01^{\mathrm{a}}$ & $1188.75^{\mathrm{b}}$ & $1271.50^{\mathrm{b}}$ & 15.35 & 0.02 \\
Crypt depth $(\mu \mathrm{m})$ & 216.90 & 254.30 & 240.73 & 240.30 & 264.45 & 9.11 & 0.75 \\
V/C & 6.22 & 5.43 & 5.60 & 5.02 & 4.95 & 0.23 & 0.59 \\
\hline
\end{tabular}

${ }^{1}$ Supplemented with zinc lactate on the basal diet, and the additive dosage was $40 \mathrm{mg} / \mathrm{kg}, 60 \mathrm{mg} / \mathrm{kg}$, $80 \mathrm{mg} / \mathrm{kg}$, respectively; $Z L$, zinc lactate

${ }^{2}$ Supplemented with zinc sulfate on the basal diet, and the additive dosage was $80 \mathrm{mg} / \mathrm{kg} ; Z S$, zinc sulfate

${ }^{3}$ Data were obtained by one-way ANOVA, and difference significance was obtained by Duncan's multiple comparisons and that does not comply with the normal distribution or homogeneity; then, the significance was conducted by the Kruskal-Wallis test (repetition $n=6$ ) that supplementation of $60 \mathrm{mg} / \mathrm{kg} \mathrm{ZL}$ increased the content of serum total protein, albumin, and activity of GSH-Px.

\section{Gene Expression of Hepatic Metallothionein}

As shown in Fig. 1, the metallothionein mRNA expression in the liver was affected by treatment $(P<0.01)$. Compared with the control, ZL80 and ZS80 both promoted $(P<0.01)$ the metallothionein mRNA expression. It is interesting that the relative expression level of metallothionein in ZL80 was higher than that in ZS80 $(P<0.01)$. Compared with the control, the mRNA expression of metallothionein in ZL40, ZL60, and ZL80 increased $(P<0.01)$. Moreover, the ZL60 group had the highest value $(P<0.01)$. The above results

Table 6 Effects of zinc lactate supplementation on serum biochemical indexes of broilers

\begin{tabular}{|c|c|c|c|c|c|c|c|c|}
\hline Items & & ZL40 ${ }^{1}$ & $\mathrm{ZL}^{1} 0^{1}$ & $\mathrm{ZL}^{1} 0^{1}$ & $\mathrm{ZS} 80^{2}$ & Control & SEM & $P$-value ${ }^{3}$ \\
\hline \multirow[t]{2}{*}{ Total protein $(\mathrm{g} / \mathrm{l})$} & $38 \mathrm{~d}$ & $35.74^{\mathrm{ab}}$ & $39.74^{\mathrm{a}}$ & $35.30^{\mathrm{b}}$ & $33.12^{\mathrm{b}}$ & $34.91^{\mathrm{b}}$ & 0.68 & 0.04 \\
\hline & $62 \mathrm{~d}$ & 38.73 & 37.9 & 38.03 & 38.93 & 37.68 & 0.62 & 0.97 \\
\hline \multirow[t]{2}{*}{ Albumin (g/l) } & $38 \mathrm{~d}$ & $15.71^{\mathrm{ab}}$ & $17.30^{\mathrm{a}}$ & $16.37^{\mathrm{ab}}$ & $15.03^{b}$ & $15.28^{b}$ & 0.28 & 0.07 \\
\hline & $62 \mathrm{~d}$ & 16.17 & 16.19 & 15.55 & 16.4 & 16.48 & 0.21 & 0.68 \\
\hline \multirow[t]{2}{*}{ Urea $(\mathrm{mmol} / \mathrm{l})$} & $38 \mathrm{~d}$ & 0.61 & 0.42 & 0.48 & 0.38 & 0.34 & 0.03 & 0.12 \\
\hline & $62 \mathrm{~d}$ & 0.36 & 0.36 & 0.32 & 0.34 & 0.31 & 0.01 & 0.47 \\
\hline \multirow[t]{2}{*}{ Cholesterol (mmol/l) } & $38 \mathrm{~d}$ & 3.83 & 4.69 & 4.15 & 3.84 & 3.93 & 0.15 & 0.33 \\
\hline & $62 \mathrm{~d}$ & 3.71 & 4.35 & 3.90 & 4.02 & 4.13 & 0.09 & 0.22 \\
\hline \multirow[t]{2}{*}{ Alkaline phosphatase (U/l) } & $38 \mathrm{~d}$ & 4018.47 & 4355.23 & 3440.71 & 3727.32 & 3613.36 & 286.51 & 0.90 \\
\hline & $62 \mathrm{~d}$ & $1640.52^{b}$ & $2136.68^{a b}$ & $2930.26^{\mathrm{a}}$ & $3066.87^{\mathrm{a}}$ & $2232.46^{\mathrm{ab}}$ & 168.93 & 0.053 \\
\hline \multirow[t]{2}{*}{ MDA (nmol/mL) } & $38 \mathrm{~d}$ & 3.55 & 4.06 & 3.75 & $3.33^{\mathrm{ab}}$ & 3.19 & 0.09 & 0.10 \\
\hline & $62 \mathrm{~d}$ & 3.30 & 3.04 & 2.92 & 2.81 & 3.39 & 0.09 & 0.27 \\
\hline \multirow[t]{2}{*}{ GSH-PX (U/ml) } & $38 \mathrm{~d}$ & 674.76 & 639.96 & 632.52 & 611.40 & 605.04 & 9.41 & 0.19 \\
\hline & $62 \mathrm{~d}$ & $493.29^{\mathrm{B}}$ & $517.43^{\mathrm{A}}$ & $495.04^{\mathrm{B}}$ & $470.78^{\mathrm{C}}$ & $459.38^{\mathrm{C}}$ & 3.46 & $<.0001$ \\
\hline \multirow[t]{2}{*}{$\mathrm{SOD}(\mathrm{U} / \mathrm{ml})$} & $38 d$ & 210.67 & 200.56 & 186.29 & 188.42 & 201.83 & 4.32 & 0.45 \\
\hline & $62 \mathrm{~d}$ & 228.38 & 236.18 & 259.98 & 236.18 & 251.06 & 5.32 & 0.41 \\
\hline
\end{tabular}

${ }^{1}$ Supplemented with zinc lactate on the basal diet, and the additive dosage was $40 \mathrm{mg} / \mathrm{kg}, 60 \mathrm{mg} / \mathrm{kg}, 80 \mathrm{mg} / \mathrm{kg}, \mathrm{respectively} ; Z L, \mathrm{zinc}$ lactate

${ }^{2}$ Supplemented with zinc sulfate on the basal diet, and the additive dosage was $80 \mathrm{mg} / \mathrm{kg} ; Z S$, zinc sulfate

${ }^{3}$ Data were obtained by one-way ANOVA, and difference significance was obtained by Duncan's multiple comparisons and that does not comply with the normal distribution or homogeneity; then, the significance was conducted by the Kruskal-Wallis test (repetition $n=6$ ) 


\section{Metallothionein}

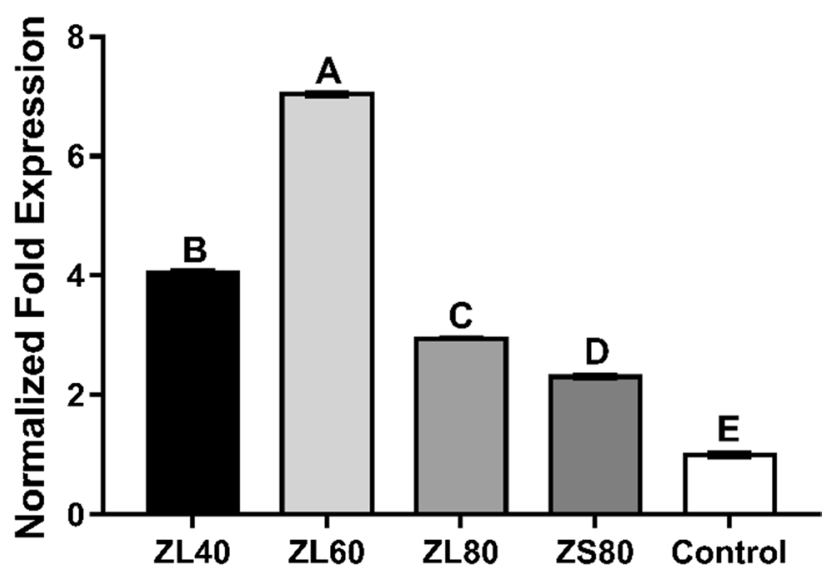

Fig. 1 Effects of zinc lactate supplementation on metallothionein mRNA expression in the liver. ZL40, ZL60, ZL80: supplemented with zinc lactate on the basal diet, and the additive dosage was $40 \mathrm{mg} / \mathrm{kg}, 60 \mathrm{mg} / \mathrm{kg}$, $80 \mathrm{mg} / \mathrm{kg}$, respectively. ZS80: supplemented with zinc sulfate on the basal diet, and the additive dosage was $80 \mathrm{mg} / \mathrm{kg}$. The different capital letters on the columns indicated a significant difference. Data were obtained by oneway ANOVA, and difference significance was obtained by Duncan's multiple comparisons and that does not comply with the normal distribution or homogeneity; then, the significance was conducted by the KruskalWallis test (repetition $n=6$ )

suggested that either inclusion of ZL or ZS in the broiler's diet promoted the hepatic metallothionein mRNA expression and dietary supplementation of ZL at $60 \mathrm{mg} / \mathrm{kg}$ had the best results in this study.

\section{Discussion}

Promoting the growth of animals and reducing the feed conversion rate has been one of the objectives in animal nutrition due to the worldwide food shortage. Hence, growth performance is normally considered as a basic indicator to evaluate the nutritional requirements of broiler and is highly valued by producers. In the present study, the addition of $40 \mathrm{mg} / \mathrm{kg}$ zinc lactate and $80 \mathrm{mg} / \mathrm{kg}$ zinc sulfate in broiler diet lowered the feed to gain ratio during the early period without affecting the ADG and ADFI, which is partly similar to the previous reports [25-27]. A previous study indicated that the weight gain of fast-growing broilers was less sensitive to the zinc levels if the zinc requirement of growth is met [28]. Hence, in terms of slow-growing broilers, a cornsoybean meal diet might be supplied sufficient $\mathrm{Zn}$ for their growth. A study has reported that ADG, ADFI, and feed conversion ratio of broiler chickens (Ross 308) were not affected by dietary organic zinc supplementation $(60 \mathrm{mg} / \mathrm{kg}$ and $120 \mathrm{mg} / \mathrm{kg}$ ) [29], which was similar to ours. However, whether dietary organic zinc supplementation has an impact on the feed conversion ratio of slow-growing broiler chicks needed more research to confirm. It is interesting to note that the feed conversion ratio of broiler chickens (Cobb 500) was improved by the interaction of zinc sources and levels [30]. This suggested that a blend of dietary organic zinc and inorganic zinc may have a synergistic promoting effect on the growth performance of broiler chickens. Recently, a study showed that zinc supplementation could increase the nutrient digestibility of mink [31]. Therefore, in the current study, the improved feed efficiency might be partly attributed to the effect of zinc lactate or zinc sulfate on the digestion, absorption, and metabolism of broilers. However, the digestibility of nutrients was not affected by sources of zinc supplementation in pigs [12]. This would require more attention in the following broiler chicken studies.

Intestinal villus (the sites of nutrient absorption) and the crypt depth (indicate the turnover rate of renewing villus) are playing a crucial role in digestive systems. Nutrient absorption ability is often evaluated by the ratio of villi height to crypt depth in animals. Zinc could promote cell proliferation and protein synthesis in the crypt base [32]. Results of the current study demonstrated that zinc lactate increased the villus height of the duodenum and ileum. Supplementation with $80 \mathrm{mg} / \mathrm{kg}$ zinc lactate and $80 \mathrm{mg} / \mathrm{kg}$ zinc sulfate also decreased the crypt depth of jejunum of broilers. Dietary zinc could improve intestinal morphology by increasing villi height or reducing crypt depth in different kinds of animals [33-35]. Previous studies showed that inorganic zinc (zinc sulfate) was more efficient in improving the villi height of jejunum compared with organic zinc (zinc glycine) [36], which was contrary to our results that villi height of jejunum in ZL80 was higher than ZS80. A recent study showed that zinc supplied in a feed as an amino acid complex $(60 \mathrm{mg} /$ $\mathrm{kg}$ ) improved the intestinal morphology with an increased villus height and the ratio of villus height to crypt depth in the duodenum [37]. This suggested that organic zinc supplementation had a better effect than inorganic zinc. The inconsistent results may be attributed to the form of organic zinc supplied and needs to be determined by the subsequent studies.

The main physiological role of serum total protein is to maintain the colloid osmotic pressure. It can reflect the hepatic protein synthesis ability and often was considered an important indicator of liver damage [38]. Both levels of serum albumin and total protein are closely related to the body's nutritional status and protein metabolism. Then, a higher level of serum total protein indicates an exuberant hepatic protein metabolism, which might be beneficial to the growth of animals. Previous research demonstrated that zinc glycine (organic zinc) increased the content of serum total protein [34]. In the current study, the inclusion of $60 \mathrm{mg} / \mathrm{kg}$ zinc lactate increased the content of total protein and albumin. These suggested that zinc lactate was beneficial to the protein synthesis in the liver of 
the broiler which might help to alleviate liver damage. Metallothionein plays an important role in the detoxification of heavy metals [39]. The increasing concentration of metallothionein can be also beneficial to liver function. Current results showed that supplementation with zinc lactate $(40 \sim 80 \mathrm{mg} / \mathrm{kg})$ and zinc sulfate $(80 \mathrm{mg} / \mathrm{kg})$ in diet promoted the metallothionein gene expression, which was in accordance with Min et al. (2019) [13]. Furthermore, the content of metallothionein could be a crucial indicator of the zinc status of the body and suitable for analysis of bioavailability $[28,40]$. Interestingly, the content of metallothionein in ZL40, ZL60, and ZL80 groups was higher than in ZS80 and control. It proved zinc lactate has a higher bioavailability than inorganic zinc and thus more beneficial to liver health. $\mathrm{Zn}$ can bind to the metal reactive element transcription factor, which could recognize and initiate the transcription of metallothionein [4, 41, 42]. This may be the reason why the content of metallothionein in tissues can be used as an indicator of zinc status [43].

$\mathrm{Zn}$ is an important component of various enzymes involved in multiple biochemical metabolic processes [4]. Alkaline phosphatase is often used to evaluate the body utilization of $\mathrm{Zn}$ and increased activity of alkaline phosphatase refers to a higher utilization rate of $\mathrm{Zn}$. In the present study, compared with the control, the activity of alkaline phosphatase in ZL80 and ZS80 increased by $31.26 \%$ and $37.37 \%$ $(P>0.05)$, respectively. Combined with the increased hepatic metallothionein content, these results suggested that supplementing zinc lactate had a higher bioavailability than zinc sulfate which was consistent with previous research [6]. Content of zinc in tibia ash was used to evaluate the bioavailability of zinc in a previous study [6]. Unfortunately, we did not collect the tibia samples. Zinc is a key component of some antioxidant enzymes like SOD [12, 44] and its beneficial effects on oxidative stress have been widely reported [44-46]. Some previous studies indicated that zinc methionine (organic zinc) increased the activities of serum SOD and GSH-Px of broilers [17, 47]. This was partly consistent with our current study that zinc lactate increased the activity of serum GSH-Px compared with ZS80 and the control group. This may derive from the increased concentration of active GSH-Px [48]. It suggested zinc lactate is more beneficial to alleviate oxidative stress, thus contributing to animals' health. Dietary Zn did not change the activity of liver SOD [28] and it was consistent with our current results. Additionally, what calls for special attention is that zinc could inhibit GSH-Px activity and induce oxidative stress at a high level [49-52]. Few changes in oxidative stress parameters were observed on the broilers in the ZL group. Therefore, it would be interesting to investigate whether supplementation of ZL would exert a beneficial impact on the antioxidant status under challenging conditions such as under a high ambient temperature condition.
In summary, supplementing ZL could decrease the feed to gain ratio and improve small intestinal morphology by increasing the villus height and the ratio of villus height to crypt depth. It can also increase the concentration of serum total protein and albumin as well as the activity of GSHPx and the content of hepatic metallothionein. The possible reason could be attributed to its higher bioavailability, especially with the dosage at $60 \mathrm{mg} / \mathrm{kg}$.

Acknowledgements The authors all wish to acknowledge the Foshan University for providing the animal experimental site and ensuring the progress of the scientific experiment smoothly and acknowledge the Guangdong Xingtengke Biotechnology Co., Ltd., for experimental material assistance.

Author Contributions Lina Long and Huihua Zhang designed the experiment; Huihua Zhang and Xichen Zhao provided helpful suggestions; statistical analysis of all data, original draft wrote, and modified were completed by Xichen Zhao; Haojie Li conducted the animal feeding and the sample analysis; Haojie Li, and Xia Yan, participated in the sample collection.

Funding The research work was supported by the Innovation Team Construction Project of the Poultry Industry Technology System of Modern Agriculture in Guangdong Province (2019KJ28), Scientific Research Foundation in the Higher Education Institutions of Educational Commission of Guangdong Province (2017GCZX006), Project in Key Areas of Serving Rural Revitalization of Department of Education of Guangdong Province (2019KZDZX2006), and Special Fund for Science and Technology of Guangdong Province (DZX20192520309), Teachers' Characteristic Innovation Research Project of Guangdong University Research Findings Commercialzation Center in Guangdong Province (2020SWYY02), Open fund of Key Laboratory of Animal Nutritional Physiology and Metabolic Processes of Hunan Province, Institute of Subtropical Agriculture, Chinese Academy of Sciences in Hunan Province (ISA2020112).

Data Availability The data used to support the findings are all included in the article.

\section{Declarations}

Ethics Approval All experimental procedures refer to the animals were approved by the Animal Care and Use Committee of Foshan University, which were in accordance with ethical standards in Laboratory animal-guideline for ethical review of animal welfare (The National Standard of the People's Republic of China GB/T 35892-2018).

Conflict of Interest The authors declare no competing interests.

Open Access This article is licensed under a Creative Commons Attribution 4.0 International License, which permits use, sharing, adaptation, distribution and reproduction in any medium or format, as long as you give appropriate credit to the original author(s) and the source, provide a link to the Creative Commons licence, and indicate if changes were made. The images or other third party material in this article are included in the article's Creative Commons licence, unless indicated otherwise in a credit line to the material. If material is not included in the article's Creative Commons licence and your intended use is not permitted by statutory regulation or exceeds the permitted use, you will need to obtain permission directly from the copyright holder. To view a copy of this licence, visit http://creativecommons.org/licenses/by/4.0/. 


\section{References}

1. Manangi MK, Vazquez-Añon M, Richards JD, Carter S, Buresh RE, Christensen KD (2012) Impact of feeding lower levels of chelated trace minerals versus industry levels of inorganic trace minerals on broiler performance, yield, footpad health, and litter mineral concentration. J Appl Poult Res 21(4):881-890. https:// doi.org/10.3382/japr.2012-00531

2. Ao T, Pierce JL, Pescatore AJ, Cantor AH, Dawson KA, Ford MJ, Paul M (2011) Effects of feeding different concentration and forms of zinc on the performance and tissue mineral status of broiler chicks. Br Poult Sci 52(4):466-471. https://doi.org/10. 1080/00071668.2011.588198

3. Kambe T, Tsuji T, Hashimoto A, Itsumura N (2015) The physiological, biochemical, and molecular roles of zinc transporters in zinc homeostasis and metabolism. Physiol Rev 95(3):749-784. https://doi.org/10.1152/physrev.00035.2014

4. Marreiro D, Cruz K, Morais J, Beserra J, Severo J, de Oliveira A (2017) Zinc and oxidative stress: current mechanisms. Antioxidants 6(2):24. https://doi.org/10.3390/antiox6020024

5. Oteiza PL, Olin KL, Fraga CG, Keen CL (1996) Oxidant defense systems in testes from zinc-deficient rats. Proc Soc Exp Biol Med 213(1):85-91. https://doi.org/10.3181/00379727-213-44040

6. Star L, van der Klis JD, Rapp C, Ward TL (2012) Bioavailability of organic and inorganic zinc sources in male broilers. Poult Sci 91(12):3115-3120. https://doi.org/10.3382/ps.2012-02314

7. National Research Council (1994) Nutrient requirements of poultry. (9th rev. ed). National Academies Press, Washington, DC.

8. Burrell AL, Dozier WA, Davis AJ, Compton MM, Freeman ME, Vendrell PF, Ward TL (2004) Responses of broilers to dietary zinc concentrations and sources in relation to environmental implications. Br Poult Sci 45(2):225-263. https://doi.org/10.1080/00071 660410001715867

9. Salim HM, Lee HR, Jo C, Lee SK, Lee BD (2011) Supplementation of graded levels of organic zinc in the diets of female broilers: effects on performance and carcase quality. Br Poult Sci 52(5):606-612. https://doi.org/10.1080/00071668.2011.616485

10. Tang Z, Wen C, Li P, Wang T, Zhou Y (2014) Effect of zincbearing zeolite clinoptilolite on growth performance, nutrient retention, digestive enzyme activities, and intestinal function of broiler chickens. Biol Trace Elem Res 158(1):51-57. https://doi. org/10.1007/s12011-014-9900-3

11. Leeson S, Caston L (2008) Using minimal supplements of trace minerals as a method of reducing trace mineral content of poultry manure. Anim Feed Sci Technol 142(3-4):339-347. https://doi. org/10.1016/j.anifeedsci.2007.08.004

12. Uniyal S, Garg AK, Jadhav SE, Chaturvedi VK, Mohanta RK (2017) Comparative efficacy of zinc supplementation from different sources on nutrient digestibility, hemato-biochemistry and anti-oxidant activity in guinea pigs. Livest Sci 204:59-64. https:// doi.org/10.1016/j.livsci.2017.08.009

13. Min YN, Liu FX, Qi X, Ji S, Cui L, Wang ZP, Gao YP (2019) Effects of organic zinc on tibia quality, mineral deposit, and metallothionein expression level of aged hens. Poult Sci 98(1):366-372. https://doi.org/10.3382/ps/pey386

14. Kibet LC, Allen AL, Church C, Kleinman PJA, Feyereisen GW, Saporito LS, Hashem F, May EB, Way TR (2013) Transport of dissolved trace elements in surface runoff and leachate from a Coastal Plain soil after poultry litter application. J Soil Water Conserv 68(3):212-220. https://doi.org/10.2489/jswc.68.3.212

15. Huang D, Zhuo Z, Fang S, Yue M, Feng J (2016) Different zinc sources have diverse impacts on gene expression of zinc absorption related transporters in intestinal porcine epithelial cells. Biol Trace Elem Res 173(2):325-332. https://doi.org/10.1007/ s12011-016-0655-x
16. Swain PS, Rao SBN, Rajendran D, Dominic G, Selvaraju S (2016) Nano zinc, an alternative to conventional zinc as animal feed supplement: a review. Anim Nutr 2(3):134-141. https://doi.org/10. 1016/j.aninu.2016.06.003

17. Saleh AA, Ragab MM, Ahmed EAM, Abudabos AM, Ebeid TA (2018) Effect of dietary zinc-methionine supplementation on growth performance, nutrient utilization, antioxidative properties and immune response in broiler chickens under high ambient temperature. J Appl Anim Res 46(1):820-827. https://doi.org/10. 1080/09712119.2017.1407768

18. Wang R, Xin A, Zhang C, Li M, Mei W, An Q, Chen K, Guo R (2014) Effects of zinc lactate on intestinal morphology, mRNA expressions of metallothioneins 1 in intestinal mucosa and acute phase proteins in tissues of weaner piglets (in Chinese). Chin J Anim Nutr 26(04):1068-1076

19. Yan JY, Zhang GW, Zhang C, Tang L, Kuang SY (2017) Effect of dietary organic zinc sources on growth performance, incidence of diarrhoea, serum and tissue zinc concentrations, and intestinal morphology in growing rabbits. World Rabbit Sci 25(1):43. https://doi.org/10.4995/wrs.2017.5770

20. Han G, Yu B, Chen D, Xiang Z, Qi H, Chen H, Mao Q, Mao X, Huang $Z$ (2012) Effects of lactate on cell proliferation and relatedregulatory genes mRNA expression in porcine jejunal epithelial cells IPEC-J2 (in Chinese). Acta Vet Zootech Sin 43(05):740-747

21. Cai SJ, Wu CX, Gong LM, Song T, Wu H, Zhang LY (2012) Effects of nano-selenium on performance, meat quality, immune function, oxidation resistance, and tissue selenium content in broilers. Poult Sci 91(10):2532-2539. https://doi.org/10.3382/ ps.2012-02160

22. Bordajandi LR, Gómez G, Abad E, Rivera J, González MJ (2004) Survey of persistent organochlorine contaminants (PCBs, PCDD/ $\mathrm{Fs}$, and PAHs), heavy metals $(\mathrm{Cu}, \mathrm{Cd}, \mathrm{Zn}, \mathrm{Pb}$, and $\mathrm{Hg})$, and arsenic in food samples from Huelva (Spain): levels and health implications. J Agric Food Chem 52(4):992-1001. https://doi.org/10. 1021/jf030453y

23. Varun A, Karthikeyan N, Muthusamy P, Raja A, Ruban SW (2017) Real time PCR based expression of metallothionein and evaluation of $\mathrm{Zn}$ bioavailability in chickens fed zinc oxide and zinc methionine. Int J Curr Microbiol Appl Sci 6(7):845-849. https://doi.org/10.20546/ijcmas.2017.607.103

24. Livak KJ, Schmittgen TD (2001) Analysis of relative gene expression data using real-time quantitative PCR and the $2-\Delta \Delta \mathrm{CT}$ method. Methods 25(4):402-408. https://doi.org/10.1006/meth. 2001.1262

25. Pacheco BHC, Nakagi VS, Kobashigawa EH, Caniatto ARM, Faria DE, Faria Filho DE (2017) Dietary levels of zinc and manganese on the performance of broilers between 1 to 42 days of age. Braz J Poultry Sci 19(2):171-178. https://doi.org/10.1590/ 1806-9061-2016-0323

26. Vieira MM, Ribeiro AML, Kessler AM, Moraes ML, Kunrath MA, Ledur VS (2013) Different sources of dietary zinc for broilers submitted to immunological, nutritional, and environmental challenge. J Appl Poult Res 22(4):855-861. https://doi.org/10.3382/ japr.2013-00753

27. Yalçinkaya I, Çinar M, Yildirim E, Erat S, Başalan M, Güngör $T$ (2016) The effect of prebiotic and organic zinc alone and in combination in broiler diets on the performance and some blood parameters. Ital J Anim Sci 11(3):e55. https://doi.org/10.4081/ ijas.2012.e55

28. Huang YL, Lu L, Luo XG, Liu B (2007) An optimal dietary zinc level of broiler chicks fed a corn-soybean meal diet. Poult Sci 86(12):2582-2589. https://doi.org/10.3382/ps.2007-00088

29. Akbari MKR, Bakhshalinejad R, Hassanabadi A, Ferket P (2017) Effects of dietary organic zinc and $\alpha$-tocopheryl acetate supplements on growth performance, meat quality, tissues minerals, and 
$\alpha$-tocopherol deposition in broiler chickens. Poult Sci 96(5):12571267. https://doi.org/10.3382/ps/pew386

30. Mwangi S, Timmons J, Ao T, Paul M, Macalintal L, Pescatore A, Cantor A, Ford M, Dawson KA (2017) Effect of zinc imprinting and replacing inorganic zinc with organic zinc on early performance of broiler chicks. Poult Sci 96(4):861-868. https://doi.org/ $10.3382 / \mathrm{ps} /$ pew 312

31. Cui H, Zhang TT, Nie H, Wang ZC, Zhang XL, Shi B, Yang FH, Gao XH (2017) Effects of sources and concentrations of zinc on growth performance, nutrient digestibility, and fur quality of growing-furring female mink (Mustela vison)1. J Anim Sci 95(12):5420-5429. https://doi.org/10.2527/jas2017.1810

32. Tako E, Ferket P, Uni Z (2005) Changes in chicken intestinal zinc exporter mRNA expression and small intestinal functionality following intra-amniotic zinc-methionine administration. J Nutr Biochem 16(6):339-346. https://doi.org/10.1016/j.jnutbio.2005. 01.002

33. Payne RL, Bidner TD, Fakler TM, Southern LL (2006) Growth and intestinal morphology of pigs from sows fed two zinc sources during gestation and lactation1,2. J Anim Sci 84(8):2141-2149. https://doi.org/10.2527/jas.2005-627

34. Feng J, Ma WQ, Niu HH, Wu XM, Wang Y, Feng J (2009) Effects of zinc glycine chelate on growth, hematological, and immunological characteristics in broilers. Biol Trace Elem Res 133(2):203211. https://doi.org/10.1007/s12011-009-8431-9

35. Wang Y, Niu H, Ma W, Liu S, Feng J (2010) Effects of dietary zinc glycine chelate on growth performance, immunological parameters and intestinal morphology in weanling piglets (in Chinese). Chin J Anim Nutr 22(01):176-180

36. Levkut M, Fukasová M, Bobíková K, Levkutová M, Čobanová K, Levkut M (2017) The effect of inorganic or organic zinc on the morphology of the intestine in broiler chickens. Folia Vet 61(3):52-56. https://doi.org/10.1515/fv-2017-0027

37. De Grande A, Leleu S, Delezie E, Rapp C, De Smet S, Goossens E, Haesebrouck F, Van Immerseel F, Ducatelle R (2020) Dietary zinc source impacts intestinal morphology and oxidative stress in young broilers. Poult Sci 99(1):441-453. https://doi.org/10.3382/ ps/pez525

38. Robert DD, A LJ, S NF, R GD, S KR, B SL (2000) Diagnosis and monitoring of hepatic injury. I. Performance characteristics of laboratory tests. Clin Chem 46(12). https://doi.org/10.1016/ S0009-8981(00)00329-6

39. Udom AO, Brady FO (1980) Reactivation in vitro of zincrequiring apo-enzymes by rat liver zinc-thionein. Biochem $\mathrm{J}$ 187(2):329-335. https://doi.org/10.1042/bj1870329

40. Fleet JC, Qureshi MA, Dietert RR, Mccormick CC (1988) Tissuespecific accumulation of metallothionein in chickens as influenced by the route of zinc administration. J Nutr 118(2):176-182. https:// doi.org/10.1093/jn/118.2.176
41. Blanchard RK, Cousins RJ (1996) Differential display of intestinal mRNAs regulated by dietary zinc. Proc Natl Acad Sci U S A 93(14):6863-6868. https://doi.org/10.1073/pnas.93.14.6863

42. Liuzzi JP, Blanchard RK, Cousins RJ (2001) Differential regulation of zinc transporter 1, 2, and 4 mRNA expression by dietary zinc in rats. J Nutr 131(1):46-52. https://doi.org/10.1038/sj.ijo. 0801535

43. Aydemir TB, Blanchard RK, Cousins RJ (2006) Zinc supplementation of young men alters metallothionein, zinc transporter, and cytokine gene expression in leukocyte populations. Proc Natl Acad Sci U S A 103(6):1699-1704. https://doi.org/10.1073/pnas. 0510407103

44. Prasad AS, Kucuk O (2002) Zinc in cancer prevention. Cancer Metastasis Rev 3-4(21):291-295. https://doi.org/10.1023/A: 1021215111729

45. Shaheen AA, El-Fattah AAA (1995) Effect of dietary zinc on lipid peroxidation, glutathione, protein thiols levels and superoxide dismutase activity in rat tissues. Int J Biochem Cell Biol 27(1):89. https://doi.org/10.1016/1357-2725(94)00053-0

46. Sahin K, Sahin N, Kucuk O, Hayirli A, Prasad AS (2009) Role of dietary zinc in heat-stressed poultry: a review. Poult Sci 88(10):2176-2183. https://doi.org/10.3382/ps.2008-00560

47. Reza AMK, Reza B, Mojtaba S (2016) Effect of dietary zinc and $\alpha$-tocopheryl acetate on broiler performance, immune responses, antioxidant enzyme activities, minerals and vitamin concentration in blood and tissues of broilers. Anim Feed Sci Technol 221:1226. https://doi.org/10.1016/j.anifeedsci.2016.08.016

48. Eide DJ (2011) The oxidative stress of zinc deficiency. Metallomics 3(11):1124. https://doi.org/10.1039/c1mt00064k

49. Jemai H, Messaoudi I, Chaouch A, Kerkeni A (2007) Protective effect of zinc supplementation on blood antioxidant defense system in rats exposed to cadmium. J Trace Elem Med Biol 21(4):269-273. https://doi.org/10.1016/j.jtemb.2007.08.001

50. Messaoudi I, El Heni J, Hammouda F, Saïd K, Kerkeni A (2009) Protective effects of selenium, zinc, or their combination on cadmium-induced oxidative stress in rat kidney. Biol Trace Elem Res 130(2):152-161. https://doi.org/10.1007/s12011-009-8324-y

51. Iszard MB, Liu J, Klaassen CD (1995) Effect of several metallothionein inducers on oxidative stress defense mechanisms in rats. Toxicology 104(1-3):25-33. https://doi.org/10.1016/0300483X(95)03118-Y

52. Li M, Hu C, Zhu Q, Chen L, Kong Z, Liu Z (2006) Copper and zinc induction of lipid peroxidation and effects on antioxidant enzyme activities in the microalga Pavlova viridis (Prymnesiophyceae). Chemosphere 62(4):565-572. https://doi.org/10.1016/j. chemosphere.2005.06.029

Publisher's Note Springer Nature remains neutral with regard to jurisdictional claims in published maps and institutional affiliations. 